\title{
Sosialisasi Budidaya Tanaman Porang Di Lahan Kosong Pada Masyarakat Dan Petani Di Kecamatan Praya Barat Lombok Tengah
}

\author{
Ismail Yasin $^{1^{*}}$, Joko Priyono $^{1}$, Bustan ${ }^{1}$ \\ ${ }^{I}$ Program Studi Ilmu Tanah, Fakultas Pertanian Universitas Mataram, Mataram, Indonesia.
}

Article history

Received: 7 Juni 2021

Revised: 8 Juni 2021

Accepted: 5 Juli 2021

*Corresponding Author: Ismail Yasin, Program Studi Ilmu Tanah, Fakultas

Pertanian Universitas

Mataram, Mataram,

Indonesia.

Email:

ismailyasinpsit@gmail.com
Abstract: Porang, a herbaceous plant endemic of Lombok Island now has a very high value because it is very salable as an export item, in addition, porang is a functional food ingredient and very useful for people with Diabetes Melliatus because of its high glucomannan content. However, not many people in South Lombok, especially the people of the West Praya sub-district, know this plant because the plant is already extinct or not found growing wild in that area. The purpose of this community service activity is to introduce porang plants to community groups in Batujai Village and Mangkung Village, West Praya District and invite them to plant porang between other plants or on vacant land. Through this service activity, its benefits and economic value were introduced as well as how to cultivate porang in local soil and climate conditions, and then the formation of a porang farmer group. The results of this service indicate that most community members or farmers in Batujai Village and Mangkung Village were very enthusiastic about participating in the socialization program. The fact that none of the community members knew the porang plant. They have not been able to distinguish between porang from iles-iles (lombos) or suweg (gawok). By looking at the potential economic value of porang, most of the people who attended the meeting were very enthusiastic about becoming porang farmers and forming a special porang farmer group. To maximize their knowledge of porang cultivation, the extension team prepared an online source of information.

Keywords: endemic; functional; glucomannan; food; services

Abstrak: Porang, suatu tumbuhan terna endemik Pulau Lombok sekarang ini mempunyai nilai yang sangat tinggi karena sangat laku sebagai barang ekspor, di samping itu, porang merupakan bahan pangan fungsional yang sangat bermanfaat bagi penderita Diabetes melliatus karena kandungan glukomannan yang tinggi. Namun demikian tidak banyak masyarakat di Lombok Selatan, terutama masyarakat kecamatan Praya Barat yang mengenal tumbuhan tersebut karena tumbuhan tersebut sudah punah atau tidak ditemukan tumbuh liar di tempat itu. Tujuan dari kegiatan pengabdian kepada masyarakat ini adalah memperkenalkan tanaman porang kepada kelompok masyarakat di Desa Batujai dan Desa Mangkung, Kecamatan Praya Barat dan mengajak mereka untuk menanam porang di sela-sela tanaman lain atau di lahan kosong. Melalui kegiatan pengabdian ini diperkenalkan manfaatnya dan nilai ekonomi serta cara membudidayakan porang pada kondisi tanah dan iklim setempat. Selanjutnya dilakukan pembentukan kelompok petani porang. Hasil dari pengabdian ini menunjukkan bahwa sebagian besar anggota masyarakat atau petani di Desa Batujai maupun di Desa Mangkung sangat anthusias mengikuti program sosialisasi tersebut. Ternyata tidak satupun dari anggota masyarakat yang mengenal tanaman porang. Mereka belum dapat membedakan anatara porang dari iles-iles (lombos) atau suweg (gawok). Dengan melihat potensi nilai ekonomi dari porang, sebagian besar masyarakat yang mengikutu pertemuan sangat anthusias menjadi petani penanam porang dan membentuk kelompok tani khusus porang Untuk memaksimalkan pengetahuan budidaya porang, tim penyuluh mempersiapkan sumber informasi online.

Kata kunci: endemic; fungsional; glukomannan; pangan; pengabdian 


\section{PENDAHULUAN}

Porang (Amorphophallus muelleri. Blum) adalah salah satu tumbuhan terna yang sekarang ini mulai dilirik potensi ekonominya oleh banyak pihak. Tanaman ini mengandung senyawa karbohidrat yang khas yang ternyata mempunyai banyak khasiat untuk kesehatan tubuh (P4I, 2013; Sumarwoto, 2012), dan juga sebagai bahan industri karena kandungannya merupakan bahan lem yang tahan panas (Koswara, 2013). Sebagai bahan pangan fungsional umbi porang mengandung senyawa glucomannan yang sangat tinggi (hingga 40\%). Glokumanan ini sangat baik dikonsumsi oleh penderita Diabetes karena dapat menurunkan gula darah (Saputra, et al. 2010; Chairiyah et al. 2014). Sebagai makanan tepung porang dijadikan bahan pencampur untuk membuat mie. Mie yang terbuat dari campuran tepung terigu dan tepung porang tekstur lebih kenyal sehingga sangat disukai oleh konsumen di negaranegara Jepang, Korea Selatan, China dan Taiwan (Saputra, et al., 2010; Ramadhani, 2020).

Di Indonesia, umbi porang merupakan makanan sekunder, bahkan tersier. Hal ini disebabkan karena porang hanya mau dimakan bila beras, jagung, ubi kayu dan ubi jalar sudah habis persediaanya. Dalam kondisi seperti itu masyarakat akan memakan dedaunan dan umbi-umbian apa saja asal tidak beracun, Ada kandungan asam oksalat pada porang dan iles-iles (lombos) menyebabkan umbi dari jenis ini kurang diminati walaupun dalam kondisi krisis pangan (Widyastuti, 2012).

Masyarakat Sasak di Pulau Lombok tidak begitu mengenal tanaman porang walaupun sangat akrab dengan suweg (Amorphophallus paeonifolius). Umbi suweg mengandung karbohidrat yang tinggi dan tidak mengandung kalsium oksalat, sehingga dapat dikonsumsi langsung setelah direbus atau dibakar, dapat juga dijadikan berbagai pangan olahan. Sayangnya minat masyarakat terhadap makanan dari suweg sangat rendah sehingga petani enggan membudidayakan suweg untuk tujuan bisnis. Mereka menanam beberapa pohon di halaman atau di kebunnya untuk dikonsumsi sendiri. Suweg dan umbi-umbian lain mulai dilirik atau dicari masyarakat bila cadangan beras dari pemerintah menipis.

Apabila harga beras melonjak tak terkendali sehingga rakyat kecil tidak mampu lagi membeli beras sebagai makanan pokoknya. Mereka akan mencari bahan pangan alternatif dari umbi-umbian mulai dari ubi jalan, ubi kayu, talas, uwi, gembili, gadung dan berbagai umbi-umbian lain. Rakyat Indonesia mengkonsumsi suweg, talas dan umbian lain, yang tak lazim sebagai bahan pangan untuk mengganti beras yang langka, Hal semacam ini pernah terjadi di Pulau Lombok bagian selatan pada tahun 1960an (Yasin, 2002). Pada waktu itu penduduk Pulau Lombok bagian selatan mengalami paceklik (kekurangan bahan pangan) akibat gagal tanam dan gagal panen padi tahun sebelumnya akibat kekeringan (Yasin , 2002). Saat itu lembaga yang mengurus logistik untuk rakyat Bulog belum ada, dan rakyat yang menyimpan padi di lumbung untuk cadangan makanan sepanjang tahun mulai habis. Hanya sedikit rakyat yang mempunyai lumbung lebih dai satu, yang mampu menyimpan padi untuk cadangan makanan lebih dari 12 bulan. Habisnya cadangan padi di lumbung menyebabkan masyarakat kemudian bergantung pada ubi jalar dan ubi kayu dan berbagai umbi-umbian lainnya. Umbi suweg (A. Paeoniifolius) dan umbi iles-iles (A. muelleri Blum) adalah umbi-umbi yang diperoleh secara gratis di kebun-kebun. Orang yang menginginkan tidak perlu meminta izin kepada pemilik kebun untuk memperolehnya. Hal ini disebabkan umbian ini masih merupakan tumbuhan liar. Berbeda halnya dengan talas, gembili, Uwi, dan jenis umbian sejenis lainnya yang memang ditanam secara sengaja oleh pemiliknya. (Rofik, et al., 2017). Setelah masa paceklik usai, musim panen padi harga beras menjadi terkendali, masyarakat yang tadinya kekurangan pangan dengan sendirinya berhenti mengkonsumsi umbi-umbian (Yasin, 2002). Cerita di atas menunjukkan bahwa umbi suweg, iles-iles dan porang mempunyai peran yang cukup penting sebagai makanan pokok pada kondisi darurat pangan.

Baru dalam beberapa tahun terakhir ini tanaman Porang dilirik banyak orang, terutama terinspirasi oleh Pak Paidi yang konon menjadi kaya-raya berkat usaha porang. Kesukaan orang-orang asing pada umbi porang sebenarnya bukan hal baru, Orang Jepang telah mengenal dan mengkonsumsi porang sejang menduduki Indonesia tahun 1942-1945. Bangsa China dan Korea mungkin mengenalnya dengan cara lain; tetapi yang jelas mereka adalah bangsa-bangsa yang telah lama mengimport porang dari negara-negara penghasil porang.

Sekarang ini permintaann produk dari porang makin meningkat. Sejalan dengan itu berbagai upaya sebenarnya telah diusahakan untuk memenuhi permintaan tersebut, namun baru sebagian kecil yang dapat dipenuhi_(Ramadhani, 2020), Sebagian besar lainnya masih berupa peluang untuk kita penuhi pada tahun-tahun 
berikutnya. Peluang permintaan yang besar tersebut tidak akan terpenuhi kalau dari sekarang tidak berupaya memperluas tanaman porang melalui proses budidaya.

Berbagai kajian yang telah dilakukan oleh para peneliti untuk meningkat hasil porang budidaya. Di Pulau Lombok, KLU usaha tersebut telah dimulai dengan memperlajari teknik pembibitan yang efisien. Penelitian lain menyangkut masalah jarak tanaman, model penaungan dan pemupukan baik dengan pupuk organik maupun pupuk anorganik. Hasil penelitian di Jawa Timur terhadap 254 ha porang (Suwardji et al, 2020) menunjukkan telah menunjukkan adanya peningkatan ekonomi bagi masyarakat yang menanaminya. Namun mereka sering menghadapi yaitu bibit umbi kurang tersedia di awal musim tanam. Untuk hal ini perlu diupayakan agar bibit (porang muda) atau katak menjadi tersedia lebih mudah dengan harga yang layak (tidak terlalu mahal). Dalam hal ini prof Suwardji et al (2000) telah mempelajari teknik penyediaan bibit dari umbi.

Kendala dengan demikian ketersediaan umbi dalam jumlah banyak dan berkelanjutan sangat penting untuk mendukung peningkatan permintaan. Suweg dan iles-iles membutuhkan naungan, sehingga sangat ideal sebagai tanaman sela pada sistem tumpangsari ataupun agroforestri. Tanaman penaung selain memberikan lindungan dari sinar matahari langsung, serasah yang dihasilkan merupakan mulsa untuk mempertahankan kelembaban tanah dan sumber hara organik (Rofik, et al., 2017).

Masalah lain yang dihadapi adalah ternyata porang hanya dikenal oleh sedikit orang, Di pulau Lombok porang memang sudah mulai diperkenalkan di kalangan petani. Misalnya di Kelompok Tani di Desa Batu Rakit dan Sambik Elen Kecamatan Bayan, KLU oleh Suwardji et al, (2020). Di Sekotong Lombok Barat porang sudah ditanam beberapa hektar dan di Sumbawa diperkenalkan oleh pemerintah kabupaten, Di Lombok Tengah tampaknya belum ada respon dari pemerintah maupun masyaraktnya Dari itu kelompok Pengabdian Kepeda Masyarakat Universitas Mataram mengusulkan melalakukan sosialisasi atau memperkenalkan potensi tanaman porang ini kepada masyarakat petani, terutama petani lahan kering, lahan-lahan

Kelompok tani di Desa Batu Rakit dan Sambik Elen. Masyarakat yang lain belum mengenal porang tetapi mereka mengenal suweg dan Iles-iles dengan baik. Tanpa porang ini dikenal luas oleh kelompok masyarakat sulit kita mencanangkan gerakan menanam porang oleh kelompok masyarakat.

Tujuan kegiatan sosialisasi porang ini adalah memperkenalkan potensi tanaman porang untuk meningkatkan pendapatan petani yang menanamnya serta memberi panduan teknik budidaya tanaman porang kepada tokoh masyarakat dan kelompok tani agar personal-personal-personal tersebut mempraktekkan budidaya porang di lahannya sendiri atau meneruskan apa yang telah diperkenalkan tersebut kepada petani lain yang berminat menanam porang di lahan miliknya.

\section{METODE}

Lokasi pengabdian ini Kecamatan Praya Barat Kabupaten Lombok Tengah. Pertemuan sosialisasi dapat dilakukan di Kantor Desa atau tempat lain yang dianggap lebih sesuai (misalnya dekat lahan petani yang bersedia lahannya ditanami porang. Sehubungan dengan COVID 19 maka kegiatan ini banyak dilakukan dengan cara melakukan secara individu atau bertamu ke rumah tokoh masyarakat, kemudian takoh masyarakat tersebut mengundang beberapa petani di rumahnya.

Tahap Kegiatan Pengabdian pada Masyarakat, yaitu 1) menetapkan lokasi dan anggota yang akan menerima kegiatan Pengabdian pada Masyarakat, 2). Bertemu dengan tokoh masyarakat atau anggota Kelompok Tani dimana dijelaskan tentang potensi tanaman porang bagi peningkatan pendapatan petani, prinsip-perinsip bercocok tanam tanaman porang pematang di sawah atau di lahan tegalannya dan cara pengolahan umbi hingga siap jual dan prospek bisnis porang; 3) pembentukan kelompok tani penanam porang dimana setiap petani dimana setiap anggota menyerahkan daftar luas lahan yang tersedia untuk ditanami porang; 4) Satu orang dari setiap kelompok tani (dua orang) penanam porang akan diajak kunjungan kerja ke kelompok tani penanam porang di desa Sambik Elen KLU untuk melihat secara langsung cara menanam porang dan melihat tanaman porang yang sudah besar.; dan 5) mahasiswa dari Fakultas pertanian Unram secara berkala akan memantau kegiatan kelompok tani penanam, porang, sehingga bila sudah ada produksi umbi yang signifikan dari porang kelompok Tani porang maka akan diadakan sosialisasi cara mengolah dan menjual hasil umbi porang. 


\section{HASIL DAN PEMBAHASAN}

\section{A. Memperkenalkan Porang dan Tempat Tumbuhnya}

Porang adalah tanaman umbi-umbian dari keluarga Araceae dan marga (Genus) Amorphophallus. Marga Amorphophallus. ini terdiri dari A. paeoniifolius, (Suweg), A. Muelleri (Iles-iles dan Porang dan A. titanum (bunga bangkai). Dalam bahasa Sasak Suweg disebut Gawok sedangkan Iles-Iles disebut Lombos mempunyai nama latin yang sama dengan Porang (A. muelleri Blum) tetapi morfologinya sedikit berbeda dengan porang. Iles-iles mempunyai batang agak kurus dan berkulit lebih kasar. Umbi iles-iles lebih berukuran lebih kecil dibanding umbi porang dan kadang-kadang berbentuk segi empat dan berwarna putih. Porang yang juga mempunyai nama latin yang sama dengan lombos tetap dipertahan bernama Porang untuk membedakannya dari lombos yang banyak tumbuh liar di kebun-kebun (Suwardji et al., 2020).

Berbeda dengan suweg dan iles-iles, porang tidak ditemukan tumbuh di pekarangan atau di kebunkebun yang tidak jauh dari rumah. Porang sekarang ini hanya tumbuh liar di kawasan hutan lindung Rinjani. Inilah yang menyebabkan masysrakat sasaran di Desa Batujai maupun di Mangkung ini masih belum tahu yang namanya tanaman Porang. Kami memperkenalan rupa atau morfologi tanaman porang dan menjelaskan bedanya dengan marga tanaman Amorphophalus yang lain, yaitu dengan Suweg dan Iles-iles (Lombos). Yang jelas hanya Porang yang mempunyai khatak (bulbil) dan umbinya berwarna kuning (Sumarwoto, 2005).
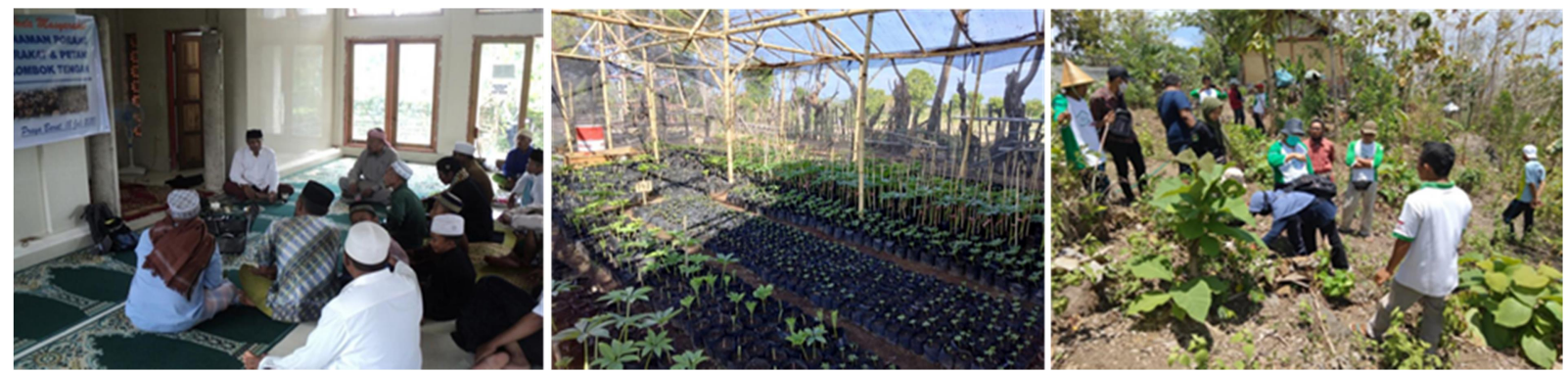

Gambar Kegiatan sosialisasi dan pengenalan teknik budidaya porang (kiri) dan bagian dari materi (vedio) terkait kegiatan pembibitan porang (tengah), serta kegiatan penanaman porang dari bibit cabutan maupun dari bibit yang disemai dalam polybag.

Setelah mereka dijelaskan perbedaan dan persamaannya dengan suweg dan Lombos, mereka mudah membayangkan tanah dan iklim atau kondisi yang diperlukan untuk menumbuhkan tanaman porang.

Yang membedakan porang dari marga amorphophallus yang lain adalah porang mempunyai umbi di daunnya yang disebut umbi daun atau bulbil atau kathak. Batangnya atau petiolenya berwarna hijau dengan totol-totol putih. Kulit batangnya bertekstur halus. Umbi porang berbentuk cekung di bagian atasnya dan bila diiris akan memperlihatkan isi berwarna kuning. Berbeda dengan suweg dan iles-iles yang umbinya berwarna putih. Beda yang tegas porang dengan iles-iles selain warna umbi di atas juga tubuh tubuhnya lebih ramping dan kasar.

Persamaan dari ketiga spesies di atas adalah batangnya memiliki bentuk tegak, lunak, berwarna hijau atau hitam dengan totol-totol putih. Satu batang tegak lurus, Di ujung batangnya akan akan muncul tiga cabang yang simetris dan cabang-cabang batangnya bercabang tiga. Mmarga Amorphophallus yang lainnnya diujung batangnya terdadan hisupnya menyukainya naungan. Tingkat kerapatan naungan berkisar 40 sampai $60 \%$

Helai daun dapat memanjang dengan ukuran 60-200 sentimeter dengan tulang-tulang daun yang kecil terlihat jelas pada permukaan bawah daun. Sementara itu, panjang tangkai daun antara 40-180 cm, dengan daundaun yang lebih tua biasanya berada di pucuk. Porang mempunyai akar primer dan batangnya dapat mencapai tinggi 1,5 meter tergantung umur dan tingkat kesuburan tanah. Umbi porang terdiri atas dua macam, yaitu umbi yang berada di dalam tanah dan umbi daun (bulbil) yang juga disebut kathak terdapat pada setiap pangkal cabang atau tangkai daun. Umbi yang banyak dimanfaatkan sebagai benih adalahi umbi daun (bulbil) atau kathak. Kathak ini biasanya berwarna kuning kusam atau kuning kecokelatan (Sumarwoto, 2005). 
Bentuk umbi dalam tanahnya khas, yaitu bulat simetris dan di bagian tengah membentuk cekungan.Jika umbi dalam tanah ini dibelah, bagian dalam umbi berwarna kuning cerah dengan serat yang halus, karena itu porang oleh masyarakat sering juga disebut iles-iles kuning

Iklim yang disukai oleh tanaman porang adalah iklim tropika basah (tipe iklim B dan C) dengan curah hujan tahunan rata-rata $2500 \mathrm{~mm}$, namun dapat juga tumbuh di daerah tipe iklim yang lebih kering yaitu pada tipe iklim D seperti di daerah Lombok bagian selatan yang mempunyai tipe iklim D4. Di Desa batujai maupun di Desa Mangkung walaupun belum dicoba menumbuhkan porang melihat keragaman pertumbuhan suweg dan iles-iles maka tidak diragukan porang juga akan tumbuh dengan baik.

Meskipun porang menyukai naungam, porang dapat juga dibudidayakan di lahan terbuka asalkan diberisedikit naungan dengan paranet. Ditinjau dari ketinggian tempat di atas permukaan laut, maka porang sangat baik ditanam di dataran rendah (ketinggian $<100 \mathrm{~m}$ dpl hingga dataran medium $(\leq 600 \mathrm{~m}$ dpl). Dengan demikian tidak ada masalah bila ditumbuhkan desa Batujai yang mempunyai ketinggian $\pm 100 \mathrm{~m}$ dpl dan desa Mangkung yang mempunyai ketinggian antara $100 \mathrm{~m}$ sampai dengan $200 \mathrm{~m}$ dpl.

Berdasarkan jenis tanah, tanaman Porang paling menyukai tanah yang subur, gembur dan banyak mengandung bahan organik. Kemasaman tanah berkisar 6,0 hingga 7.0. Tanah hendaknya bersolum cukup dalam dimana umbi dapat berkembang dengan sempurna. Namun dapat juga mengasilkan dengan baik pada tanah yang mempunyai tekstur sangat liat seperti di tanah Vertisol si Batujai dan Mangkung. Hal ini mengacu pada tanaman ubi kayu dan Suweg yang dapat tumbuh dan menghasilkan umbi atau hasil yang tinggi (15 ton/ha).

Pada dasarnya, semua jenis tanah sesuai untuk ditanami tanaman porang asalkan tanahnya subur dan mengandung bahan organik cukup tinggi. Permasalahan yang timbul di Desa Mangkung selain tanah datar jenis Vertisol juga mempunyai tanah Entisol pada lahan berbukit yang mempunyai mempunyai solum yang tipis dan permukaan tanahnya berbatu. Hal ini dapat di atasi dengan menanam porang pada lobang tanah yang dibuat yang berukuran $20 \mathrm{~cm}$ x $20 \mathrm{~cm}$ x $20 \mathrm{~cm}$ atau $0.008 \mathrm{~cm} 3$. Model tanam seperti ini memang membutuhkan waktu, tenaga dan modal tapi dapat diharapkan hasilnya berupa umbi dapat mendekati porang yang ditanam pada tanah yang gembur (Suwardji, et al., 2020). Porang pada umumnya tidak memerlukan pemupukan pupuk buatan berdosis tinggi lebih dianjurkan menambah bahan organik atau perlakuan pupuk kandang atau kompos pada dosis 5 sampai 10 ton per ha (Lebi, 2013).

\section{B. Cara Pembibitan dan Penanaman Porang}

Tidak seperti menyuluhkan tentang suatu tanaman selain porang. Pada saat dilaksanakan kegiatan PKM ini porang sedang mengalami dormansi. Oleh karena itu kami hanya dapat menunjukkan beberapa video mengenai porang termasuk video yang kami buat berkaitan kegiatan menanam porang di KLU yang dibuat satu tahun sebelumnya. Video tersebut memperlihatkan teknil pembibitan, pembuatan rumah yang diatapi dengan paranet dan penyiapan tanah dalam polybag.

Tanah dalam polybag tersebut akan ditanami dengan satu butir bulbil (kathak) pada bulan November. Bulbil dalam polybag akan mulai tumbuh dengan memperlihatkan seludang. Beberapa minggu kemudian akan tumbuh daun sehingga porang memperlihatkan tanaman porang kecil yang semperuna.

Menanam dan merawat tanaman porang sangat mudah karena tidak membutuhkan banyak waktu dan tenaga serta tidak membutuhkan pupuk atau pun pembasmi hama. Tanaman porang hampir tidak mempunyai binatang penggangu (hama dan penyakit) sehingga cukup membiarkannya tumbuh dibawah naungan pohon agar tidak terkena matahari secara langsung,

Bahkan membudidayakan porang dapat dilakukan sambil menanam berbagai jenis pohon tegakan (pohon kayu) atau tanaman penutup tanah. Tanaman porang dapat ditanam dibawah naungan pohon yang rindang diantara berbagai tanaman produktif seperti kemiri, jambu mete, dan lainnya sehingga pada saat musim panen tiba petani selain memanen porang, juga dapat memanen hasil kebun lainnnya tanpa pengurangan hasil baik hasil umbi porang maupun hasil dari tanaman pohon tegakan (Sari dan Suhartati, 2015. Suwardji et al., 2020). 
Sampai saat ini tidak banyak diinformasikan jenis hama dan penyakit yang menyerang porang. Kadangkadang ditemukan ular melilit di batang dan cabang porang. Mungkin ular bukanlah hama yang menyerang daun porang. Mungkin ular sedang berkamuflase menghindari musuh-musuh ular, karena mirip rupanya dengan pohon porang.

Pengganggu pertumbuhan yang perlu dikendalikan adalah gulma. Untuk itu, penyiangan dilakukan dengan membersihkan gulma yang dapat menjadi pesaing tanaman porang dalam hal kebutuhan air dan unsur hara. Penyiangan sebaiknya dilakukan sebulan setelah umbi porang ditanam. Penyiangan berikutnya dilakukan saat ada gulma yang muncul. Gulma yang sudah disiang lalu ditimbun di dalam lubang untuk dijadikan pupuk organik.

Tanaman porang dapat dipanen untuk pertama kali setelah umurnya mencapai 2 tahun. Umbi yang dipanen adalah umbi besar yang beratnya lebih dari $1 \mathrm{~kg} / \mathrm{umbi}$, sedangkan umbi yang masih kecil ditinggalkan untuk dipanen pada tahun berikutnya. Setelah itu, tanaman dapat dipanen setahun sekali tanpa harus menanam kembali umbinya.

Ciri-ciri porang yang siap panen adalah jika daunnya telah kering dan jatuh ke tanah. Satu pohon porang bisa menghasilkan umbi sekitar $2 \mathrm{~kg}$ dan dari sekitar 40 ribu tanaman dalam satu hektar bisa dipanen 80 ton umbi pada periode pemanenan tahun kedua (Suwardji et al., 2020). Setelah umbi dipanen, kemudian dibersihkan dari tanah dan akar. Umbi kemudian dipotong lalu dijemur, memotong umbi tersebut harus benar karena menentukan kualitas porang yang dihasilkan. Pendapatan yang dapat diperoleh petani bisa mencapai 176 juta hanya dalam sekali panen (Rofik et al., 2017).

\section{Prospek Bisnis Porang}

Prospek bisnis dari porang sangat baik, lebih baik dari bisnis jagung atau tembakau. Hal ini disebabkan permintaan porang dari luar negeri sangat besar (baru terpenuhi $\pm 20 \%$ ) sedang untuk meningkat produksi atau memperluas areal tanam porang di Indonesia perlu waktu dan banyak kegiatan sosialisasi. Saat ini beberapa peneliti melaporkan keuntungan bersih dari menanam porang sekitar Rp 77 juta rupiah pertahun kalau petani menjual dalam bentuk umbi. Keuntungan akan lebih besar kalau petani menjual dalam bentuk chips atau tepung. Keuntungan akan lebih besar lagi kalaun petani dapat membuat bibit sendiri dari panen kathak (umbi daun) maupun dari umbi.

Yang penting bagi petani adalah keuntungan tersebut relatif stabil, atau tidak berubah-ubah setiap tahun. Sebagai mana produksi tanaman laian (misalnya jagung atau tembakau) kalau terlalu banyak hargan turun drastis karena pembeli tingkat hulu berhenti membeli dan kalau sedikit pihak pembeli hulu tidak membeli karena tidak efisien. Berbeda kasusnya dengan umbi porang. Bila pihak hulu (fabrikan) berhenti membeli) porang bisa disimpan dalam tanah dan dipanen tahun berikutnya. Sampai sekarang produksi porang masih jauh dari permintaan pasar. Perlu waktu bertahun-tahun kita memproduksi porang sehingga kondisi permintaan dan penawaran berimbang. Pada kondisi berimbang ini diperkirakan teknologi pengolahan porang sudah maju dan bisa dilaksanakan oleh pengusaha kecil sehingga tepung porang banyak diserap oleh pembeli lokal untuk pangan olahan.

\section{Respon Masyarakat Sasaran Terhadap Ajakan Menanam porang}

Respon masyarakat terhadap ajakan menanam porang di pematang sawah atau di lahan tegalannya dipilahkan menjadi dua bagian:

1. Anggota masyarakat atau petani yang sangat anthusias. Kelompok masyarakat ini tergolong petani maju dan melakukan analisis usahatani dalam bertani. Mereka berorientasi keuntungan usahatani dalam menjalankan praktek sebagai petani. Tidak sekedar bercocok tanam sekedar untuk memperoleh padi yang cukup untuk cadangan pangan keluarganya sepanjang tahun. Petani yang berfikir maju akan menanam tanaman yang berharga tingg (sangat ingin mengikuti program menanam porang di bawah bimbingan kami, dan sebagian tidak begitu anthsii di pasar. Biasanya hal ini diperoleh dengan menanam tanaman atau sayuran di luar musimnya, misalnya menanam cabe pada musim hujan. Dalam hal ajakann menanam porang petani ini juga termasuk orang yang melek teknologi/ Mereka akan segera mencari informasi dari sumber lain melalui HP 
nya mengenai hal yang disuluhkan. Orang-orang ini walaupun baru mengenal tanaman porang ini setelah kegiatan PKM ini memperlihatkan contoh umbi porang (yang dibawa langsung ke ruang pertemuan segera mereka mencari informasi melalui internet mengenai seluk-beluk porang ini.

Meskipun mereka belum pernah melihat porang sebelumnya, mereka sudah mengenal dua species lain dari marga (genus) porang dan dapatbmembedakan dengan marga Amorphophallus lainnya yaitu yaitu Suweg (Gawok) dan Iles-iles (Lombos). beberapa petani pernah membudidayakan Suweg sehingga mengenal rasa dan mempunyai pengalaman menanamnya. Yang pertama adalah kelompok petani yang pada umumnya adalah masyarakat yang sudah melek teknologi (dapat menggunakan gadget) atau internet di HPnya. Hal penting yang mereka ingin pastikan dari kami (pelaksana kegiatan PKM)n adalah adanya jaminan pasar yang mudah dan harga yang stabil, tidak turun naik seoerti kebanykan komoditi pertanian lainnya. Jangan sampai setelah tanamannya telah memproduksi umbi. Pembeli nya lari atau pura-pura jual mahal dan menawarkan harga semurah-murahnya. Tidak sesuai dengan yang dijelaskan oleh pelaksana kegiatan PKM.

2. Kelompok yang kedua adalah kelompok yang tidak begitu anthusias mengikuti program ajakan menanam porang. Kelompok ini umumnya terdiri dari mesyarakat petani yang berusia lanjut, buta aksara dan tidak mengenal teknologi (Gadget) maka responnya adalah tergantung pada apa yang ditawarkan peneliti. Ini biasanya berupa paket berupa benih (bibit) serta uang pemeliharaan selama tanaman tumbuh di lahannya. Mereka tidak terlalu tertarik denganpenjelasan potensi hasil dan pendapatan porang. Mereka menganggap penjelasan semacam itu adalah cerita-cerita gombal atau omong besar yang sulit dibuktikan. Mereka sampai tua menjadi petani dan mereka tidak pernah melihat seorang petani menjadi kaya karena hasil dari penjualan hasil pertaniannya. Yang mereka sering lihat adalah orang-orang menjadi kaya karena menjadi penjual hasil pertanian mereka. Mereka pada dasarnya kurang percaya dengan informasi yang diberikan oleh peneliti atau informasi dari media. Mereka banyak belajar dari pengalamannya dibina atau didampingi oleh berbagai Lembaga Pemerintah maupun oleh LSM yang pada awal program dijejali dengan berbagai cerita mulukmuluk dan diakhir pembinaan, hasil binaannya tidak berlanjut karena berbagai alasan dan kondisi, sehingga kembali ke titk nol. Inilah yang menyebabkan petani kategori ini lebih tertarik dengan paket apa yang ditawari sebelum program yang ditawarkan diterapkan oleh petani.

\section{E. Pembentukan Kelompok Petani Porang}

Pembentukan Kelompok Petani Porang dibentuk di tingkat lokal segera setelah selesai pertemuan. Jumlah anggota yang mendaftar masing 10 orang di Batujai dan 7 orang di mangkung. Visi dari kelompok Tani ini adalah meningkat pendapatan petani melalui budidaya porang, sedangkan misi mereka adalah melalkuan pembibitan, penanaman porang serta menjual hasil (umbi) secara terencana sehingga dapat memperoleh harga yang menguntungkan. Kedua kelompok tani ini menharapkan segera mendapat bantuan (subsidi) benih berupa kathak dan bimbingan langsung cara pembibitan dan cara menanam porang nanti pada waktunya.

\section{KESIMPULAN}

Pada awalnya sebagian besar petani belum mengenal atau melihat porang secara langsung, namun melalui kegiatan penyuluhan ini kini mereka telah mengetahui bahwa porang berbeda dengan iles-iles. Respon petani terhadap ajakan tim penyuluh-peneliti agar memanfaatkan lahannya untuk budidaya porang terbagi dua kelompok, yaitu sebagian besar anggota masyarakat sangat antusias. Mereka adalah petani muda atau anggota masyarakat yang berfikir maju dan moderen. Sebaliknya petani yang berumur sudah tua dan buta huruf mempunyai respon kurang antusias. Padahal, di kawasan Batujai tanaman porang dapat ditanam di pematang sawah dan berdasarkan perhitungan kasar setiap hektar lahan sawah mempunyai panjang pematang 800-1000 m sehingga setiap hektar sawah dapat ditanami 800-1000 pohon porang. Sedangkan pada lahan tegalan di Desa Mangkung porang dapat ditanam di sela-sela jagung atau ubi kayu. 


\section{Daftar Pustaka}

Chairiyah, N., N. Harijati, dan R. Mastuti. 2014. Pengaruh Waktu Panen Terhadap Kandungan Glukomanan pada Umbi Porang (Amorphophallus muelleri Blume) Periode Tumbuh Ketiga. Research Journal of Life Science, 1 (1): 37-42.

Koswara, S. 2013. Teknologi Pengolahan Umbi-umbian: Pengolahan Umbi Porang. [Modul]. Institute Pertanian Bogor.

Lebi, M. E. 2013. Kajian Konsentrasi CPPU dan Dosis Pupuk Anorganik terhadap Pertumbuhan Tanaman Porang (Amorphophallus oncophyllus). [Skripsi]. Universitas Pembangunan Nasional 'Veteran'Jawa Timur. Surabaya.

Pusat Penelitian dan Pengembangan Porang Indonesia (P4I). 2013. Budidaya dan Pengembangan Porang (Amorphophallus muelleri Blume) Sebagai Salah Satu Potensi Bahan Baku Lokal. [Modul]. Universitas Brawijaya.Malang.

Ramadhani, Y. 2020. Keuntungan Bisnis Tanaman Porang: Potensi Ekspor Hingga Rp 11,31 M. https://tirto.id/ew4b.

Sari., R dan Suhartati. 2015. Tumbuhan Porang: Prospek Budidaya Sebagai Salah Satu Sistem Agroforestry Info Teknis Eboni. 12 (2): 97-110.

Rofik, K, R. Setiahadi, I. R. Puspitawati, M. Lukito. 2017. Potensi Produksi Tanaman Porang (Amorphophallus Muelleri Blume) di Kelompok Tani Mpsdh Wono Lestari Desa Padas Kecamatan Dagangan Kabupaten Madiun. AGRI-TEK: Jurnal Ilmu Pertanian, Kehutanan dan Agroteknologi. 17(2).

Saputra, R. A., R. Mastuti, dan A. Roosdiana. 2010. Kandungan Asam Oksalat Terlarut dan Tidak Terlarut pada Umbi Dua Varian Porang (Amorphophallus muelleri Blume) di KPH Saradan, Madiun, Jawa Timur pada Siklus Pertumbuhan ketiga. [Skripsi]. Universitas Brawijaya. Malang.

Sumarwoto. 2005. Iles-iles (Amorphophallus muelleri Blume); Deskripsi dan Sifat-sifat Lainnya. Biodiversitas, 6 (3): $185-190$.

Sumarwoto. 2012. Peluang Bisnis beberapa Macam Produk Hasil Tanaman Iles Kuning di DIY Melalui Kemitraan dan Teknik Budaya. Business Conference, Yogyakarta tanggal 6 Desember 2012.

Suwardji, IGM Kusnarta, I. Yasin dan Fahrudin. 2020. Sosialisasi Penanaman Porang di KLU. (In Published) Widyastuti, E. 2012. Teknologi Pemanfaatan Porang. Universitas Brawijaya.Malang.

Yasin, I. 2002. Pengambilan Keputusan Dengan IOS dalam Kapan Hujan Turun ? Yan J, Partrige dan M.

Ma'shum (Ed). Queensland Government, Department of Primary Industry 